\title{
A Sociolinguistic Study of American Slang
}

\author{
Yanchun Zhou \\ Changchun University of Science and Technology, Changchun, China \\ Yanhong Fan \\ Changchun University of Science and Technology, Changchun, China
}

\begin{abstract}
Slang is widely used by people from all walks of life. American slang is formed and developed with American history. It has its unique characteristics and functions. American slang reflects American culture. A sociolinguistic study of American slang helps people know more about American culture and society. This paper discusses American slang from the following perspectives, features of American slang, individual factors influencing American slang, social factors influencing American slang as well as the social functions of American slang.
\end{abstract}

Index Terms-American slang, sociolinguistics, American culture

\section{INTRODUCTION}

An informal style of speech often sees the frequent occurrence of slang, which may be a single word, a group of words or a sentence. Slang is highly informal and is often used in colloquial speech. It is a part of a language that is usually outside of conventional or standard usage and that may consist of both newly coined words and phrases and of new or extended meanings attached to established terms (Chen Linhua, 2006, p.260). Slang is kind of speech variety. Speech variety, or language variety, refers to any distinguishable form of speech used by a speaker or a group of speakers. Linguistic features of a speech variety can be found at the lexical, the phonological, the morphological, or the syntactical level of the language (Dai \& He, 2010, p.111). Variety is considered a more neutral term than terms such as standard or non-standard language and dialects. American slang as one part of Americanism will become even more international as the development of USA and American English. Although many intelligent people consider slang is of lower acceptability in society, the trend is more obvious that the use of slang expressions in movies, television, newspapers, and magazines is noticeably increasing. From the trend, we can see American slang is becoming more and more widely used and plays an increasingly influential role in everyday discourse of American English.

As for American slang, it comes in various ways. One of them is from the different subculture groups of society. As time passing by, the developing society enlarges the resources of slang and enriches its contexts. The slang terms from subculture groups are adopted by common people, and become common people's vocabulary. Also young people are quite active in creating slang. They employ slang terms in their conversation to show their attitude against the society or their own way of thinking. Therefore we can see American slang is a product of society, it is produced and created by society and people who live in it. It is one of linguistic varieties, which we cannot separate it from its social background and social surroundings.

\section{FEATURES OF AMERICAN SLANG}

What is it exactly that differentiates slang from the standard vocabulary? Because most slang terms are simply old words given additional new meanings, slang cannot usually be distinguished on the basis of its formal or grammatical features.

\section{A. Humor}

American slang is considered as "comedy" by Americans because of its humorous effect. The humor of American slang first represented in terms of its phonetic humor. A great amount of American slangs take advantage of the euphony to achieve the aim of being easily to be understood and remembered and to get the purposes of being readable and vivid. Rhyme is a common phonetic method in American slang to get its humorous effect. There are many examples: the bee's knees (outstanding people or thing); fender-bender (a trifle); razzle-dazzle (carnival) and so on. The usage of rhyme in American slang can make people feel a sense of rhythm in sounds.

The characteristic in humor can also be shown through lexicon. NATO is an acronym, which is short for the famous North Atlantic Treaty Organization but now American people develop NATO into a slang which has a quite different meaning with the original one, that is, the new meaning of NATO is used to describe somebody or something that only says something but not puts their plans to practice.

\section{B. Conciseness}

Conciseness may not be the soul of American slang, but it is perhaps the chief feature. This is attained either by 
apocope, as in vamp for vampire, molt for muttonhead, fan for fanatic (apparently), etc., or by the substitution of an expressive monosyllable or compound of monosyllables for a longer word or description. Simp (stupid person), veep (vice president), classy (fashionable), etc. are brief and easy to speak out. When they defined a Communist as either a crank or a crook, the subject is really exhausted. It is difficult now to imagine how we got on so long without the word stunt, how they expressed the characteristics so conveniently summed up in dope-fiend or high-brow, or any other possible way of describing that mixture of the cheap pathetic and the ludicrous which is now universally labeled sob stuff.

\section{Originality}

Slang is the diction that results from the favorite game among the young and lively of playing with words and renaming things and actions; some invent new words, or mutilate or misapply the old, for the pleasure of novelty, and others catch up such words for the pleasure of being in the fashion. For example, live wire, smoker eater and flying coffin refer to "living man", "fireman", "plane" respectively. These similes are so novel and vivid that they can't be made without good imagination, while think-machine (brain), sparkler (diamond), pickers (hands), canned music (musical disk) are more vivid and expressive. Sometimes slang words are invented by a few people for the pleasure of novelty and imitated by others who like to be in fashion. Many of the slang words coined during the Second World War have passed out of use along with the events that called them into life.

\section{Instability}

Whereas the words which form the backbone of the language still show no signs of failing variety, it is unusual for slang words to remain in use for more than a few years, though some slang terms serve a useful purpose and so pass into the standard language. The vocabulary of slang changes rapidly: what is new and exiting for one generation is old-fashioned for the next. Old slang often either drifts into obsolescence or becomes accepted into the standard language, losing its eccentric color. Flapper, for instance, started life in the late $19^{\text {th }}$ century as a slang term for a young unconventional or lively woman, but subsequently moved into the general language as a specific term for such a vogue woman of the 1920s. Similarly, the use of gay in the sense "homosexual" has its roots firmly in slang of the 1930s, but is now widely accepted as standard terminology.

\section{INDIVIDUAL FACTORS INFLUENCING AMERICAN SLANG}

Idiolect is a personal dialect of an individual speaker that combines elements regarding regional, social, gender, and age variations. In other words, an individual speaker's regional and social background, his/her gender and age jointly determine the way he/she talks (Dai \& He, 2010, p.115). Slang is a kind of sociolect and idiolect has to do with separation brought about by different social and individual conditions. Then let's firstly go to some individual conditions influencing American slang.

\section{A. American Slang and Gender}

Language, like other form of social activity, has to be appropriate to the speakers using it. This is why, in many communities, men and women's speech is different. In the use of American slang, men and women differ from each other.

Most American slang is created and used by males. De Klerk also found that the gender difference in use and tolerance of slang was leveling out in contemporary society and that the stereotype of males being the primary slang users was open to question. Many types of slang words including the taboo and strongly derogatory ones, those referring to sex, women, work, money, whiskey, politics, transportation, sports, and the like refer primarily to male endeavor and interest. The majority of entries in all slang dictionaries could be labeled "primarily masculine use". Moreover, men belong to more sub-groups than do women; men create and use occupational cant and jargon; in business, men have acquaintances that belong to many different sub-groups. Women, on the other hand, still tend to be restricted to family and neighborhood friends. Women have very little of their own slang, The new words applied to women's clothing, hair styles, homes, kitchen utensils and gadgets are usually created by men. Except when she accompanies her boy friend or husband to his recreation (baseball, hunting, etc.), a woman seldom mingles with other groups. When women do mingle outside of their own neighborhood and family circles, they do not often talk of the outside world of business, politics, or other fields of general interest where new feminine names for objects, concepts, and viewpoints could evolve. Women, who do work usually replace men at men's jobs, are less involved in business life than men and have a shorter business career (often only an interim between school and marriage). The major female sub-groups contributing to American slang are: airline stewardesses, beauty-operators, chorus girls, nurses, prostitutes, and waitresses. Nowadays, due to the influence of feminist movement, women are trying to enter into the male preserve, but the majority of Americans are less tolerant of women using slang.

\section{B. American Slang and Occupation}

Generally speaking, there is an inverse relationship between the occupation variable and acceptance of slang, for the higher the training and education required for the position, the lower the tolerance for slang. Occupation is, therefore, the most discrimination variable. Furthermore, professional people are somewhat more accepting of slang than 
non-professionals .

\section{American Slang and Age}

Age factor also influences the use of American slang. American youths, especially the teenagers and college students, are the main consumers and makers of American slang. The American teenagers and college students are the fashion makers. They are radical in every aspect including their ways of using language. They are not afraid of making mistakes, but ready to explore the unknown things. They are full of curiosity, pursuit and are mad with new things. At the same time, they have a strong sense of independence; do not bend blindly to any authorities like parents and teachers. They are ready to challenge traditional conventions and customs. They tend to make good use of the slang terms created by the musicians, pop singers, or those engaged in the popular trades. For instance, the words crazy originally means mad, strange, silly, but the musicians of the pop used this word to mean a completely different meaning beautiful, excellent, or exciting.

Adults (including elderly Americans) comparatively use slang less, but sometimes they use it in some very informal environment, particularly chatting with family members or close friends. At that time, slang terms can be efficient shorthand ways to express their ideas and concepts. Not only does this make their communication more efficient, but also it reinforces their friendship.

\section{SOCIAL FACTORS INFLUENCING AMERICAN SLANG}

Sociolect refers to the linguistic variety characteristic of a particular social class. Two people who were born and brought up in the same geographical region and speak the same regional dialect may speak differently because of a number of social factors. (Dai \& He, 2010, p.113) It has to do with separation brought about by different social conditions. In other words, it means some social settings which influences American slang.

\section{A. Drug Setting and American Slang}

Drug problem is serious in America. The National Commission on Marijuana and Drug Abuse, in its extensive survey published in 1972, found that twenty-four million Americans had smoked marijuana; the incidence of use reached 40 percent in the eighteen-to-twenty-one age group, and 38 percent in the twenty-two-to-twenty-five age group. A UCLA professor was quoted in the days of hip as saying that "if a young man hasn't smoked pot by the time he' s twenty, he' s probably sick," that is, "seriously neurotic," because marijuana is "a way of life for American' s youth." Evidence from the hip era suggests that indeed huge numbers of the young were smoking it. A sample of 219 University of Kansas students in 1971 indicated that 69 percent had smoked marijuana and that 92 percent had friends who smoked it.

\section{B. Homosexuality and American Slang}

Homosexuality like gay and lesbian is becoming acceptable now. In old times, however, it is despised by people especially in American society. Sex, in the slang world, was fun and free. At the same time, sex was understood as an expression of humanness, a means of human communication that operated at the deepest level of human being. It was the "human touch, without conquest or domination, and it obviates self-consciousness and embarrassed speech". One of the most important components of the hip-era sexual revolution was the rise of public gay consciousness, and the underground press gave considerable publicity and support to that phenomenon. Although one cannot exactly argue that the hippies spawned the gay liberation movement, it is fair to say that hip tolerance of sexual activity contributed to the atmosphere in which the gay revolution could emerge.

Homosexuals and their supporters wrote frequently in the underground press, making a broadly based case for an ethics of homosexuality; their arguments were like those of the heterosexual liberationists. Miller gave five main lines of arguments: (1) Homosexuality is natural and good. "To deny the rightful existence of homosexuality is a perversion of the laws of nature..." (2) A person has a right to free sexual choice. It was a choice as legitimate as any other. While the whole world is not gay, hippies stood for nothing if not freedom of choice. (3) One should not have to hide his or her sexual preference. Homosexuality wasn't wrong, and it shouldn't' have to be secret. Gays needed to stop mimicking straights; stop censoring ourselves. (4) All private acts between consenting adults should be legal. "Blow jobs are beautiful. They are natural, basic, simple, fun...Something so important as that...should be legalized." (5) Social discrimination against homosexuals should end. Homosexuals paid taxes, but "the only things we get for our taxation are undesirable discharges and bad employment records when we are discovered in government jobs."

A large number of sexually related words enter the dictionary, providing perhaps the most dramatic example of backstage behavior moving front stage. Many of these are older terms from the gay society or from what used to be called "vulgar slang." The following examples are taken from Gozzi' s. " I would like to illustrate this movement of backstage terms to front stage by discussing the 'f word,' formerly known as 'f-,' but now dragged into the full light of day as fuck". This old Anglo-Saxon word did not appear in the controversial 1961 Webster's Unabridged, nor the 7th Edition Collegiate Dictionary (1963). After the raucous 1960s, however, the word made its way into the Collegiate dictionaries, and even into the conservative American Heritage Dictionary Second College Edition. The Collegiate dictionaries labeled it as "usually considered obscene," and the American Heritage Dictionary as "obscene," just to let us know that even permissive linguists disapproved. But there it was alone and in glorious combinations. Other sexual 
behavior came front-stage as well, especially gay culture, where many closet queens came out, and organized politically and publicly a gay liberation movement.

\section{Rock and American Slang}

Rock influenced a generation both physically and emotionally. The hippies lived and breathed it as well as believed that it was the most important new musical form to come along in centuries. To the hippies, rock was not just sound, it was part and parcel of a way of life, and its ethical dimensions were therefore substantial.

Rock, however, was communal, and thus it provided a medium for cultural communication, that is, rock can also be used as a cultural. Slang words of rock and roll also leave their marks in the American vocabulary. In the 1950s radio, which had been the nation's major mass medium, lost most of its listeners to TV. It survived by a sort of narrow casting, specializing in rock and roll for the rebellious young, news and music for drive-time audiences, and an alliance with the alarm clock in the clock radio. The transistor radio became truly portable. This formula succeeded so well that by the 1970s and 1980s, the old lower class rock songs became Bolded-oldies, and the exuberance of American music was perhaps the high point of cultural creativity in this period.

\section{The Social Functions OF American SLANG}

In surveying American slang, not only do we have to consider the social factors which influence slang, but we must recognize the part played by slang in its own character. However, the complexity of slang is immediately apparent when we examine its function. People find it not easy to give a comprehensive and satisfying answer when facing the natural question "Why is slang used at all?" or "What are the functions of slang?" Sociolinguistically speaking, the interpersonal function is the most basic function of language. Speaking of the social functions of slang, the most important point lies in that language is for communication between people. Hence the discussion of the interpersonal function of American slang is in the coming part.

\section{A. Pursuit of Self-identity}

Since different social and professional groups have different slang, thus it is considered as the symbol for dividing the professional groups in society. If somebody uses the words and expressions within a certain social group or professional group, he will blend with the group members from mentality. That is to say, if a student says a sentence containing the special college slang, he must want to get the result of showing and strengthening the emotion that he is belonging to the inside of the teenager group. The American scholar P. Roberts once pointed out that the reason people constantly use slang is that they want to show they are one of the qualified members among a certain distinct groups.

\section{B. Emotive Feeling of the Slang Users}

The emotive function reveals the speaker's attitude towards his subject. The emotive function is one of the most powerful uses of language because it is so crucial and important in changing the emotional status of an audience for or against someone or something, the emotive function help us get rid of our nervous energy when we are under stress. Psychologically, slang helps people to express their strong feeling, like group identification and so on. "Slang also has this usefulness, and I suspect that profanity is a subcategory of slang, the more elemental phenomenon". It is like dream that relieves us and takes away our psychological burden, also discharges our tension of the great burden. When people use it, they want to show them against the reality, and set them free psychologically. As Allen suggests "Slang is a class of language, among other social and psychological uses, to deny allegiance to genteel, elite, and proper society and to its standard linguistic forms". No wonder, why so many people use slang in their conversation, from common people to intellectual groups, such as doctors, lawyers, and politicians. In this aspect, slang for them not only for stressing identity or group membership, but also for the psychological need for expressing emotion, which it is the one of the basic functions of language as well.

\section{Achieving Politeness}

To conduct this discussion, the notion of register needs to be mentioned. Register refers to "manner of speaking or writing specific to a certain function, that is, characteristic of a certain domain of communication" The choice of register is affected by three factors, occasions (formal or informal), addressee (age, gender, occupation, the degree of familiarity) and the content of the conversation. And the use of slang is restrained by the three factors as well. Either the use of slang in improper occasions or the use of slang not to the right addressee, or the improper content in one's speech may ruin the friendship and good relationship with your interlocutors. Therefore, the proper use of slang facilitates setting up a certain atmosphere or maintaining social contacts. Slang is often used in informal occasions and is of importance in playing the phatic function. The use of slang can maintain the friendship and intimacy between our friends.

When slang serves the phatic function, it contributes to maintain our positive face. Language forms like greeting, farewells, comments on the weather and on clothing, etc, all serve phatic function. As with politeness in general, greetings can be analyzed within the framework of theories of 'face'. When making proper slangy greetings, friendly atmosphere may be achieved for proceeding conversation, slangy greetings such as, how's it going? What does it look like? What it is? What's going down? What's happening? What's jumping? What's shaking? What's the deal? What's up, 
G? etc, or slangy farewell expressions like, catch you later, check you on the flip side, catch you on the flip flop, check you, smell you later, smell you, are frequently used among young people. Both the slangy greetings and farewells used signal that the speaker wishes to establish a good relations or a non-threatening atmosphere with his or her friends that he or she wishes to be accepted by their peers and his or her positive face will not be threatened. In daily talks, slang plays a big role and the communications between us would not go smoothly as they are expected.

\section{CONCLUSION}

American slang is one of the language varieties in American English. It is the product of American culture and American society. It is a kind of sociolect. The paper discusses American slang from sociolinguistic point of view. It makes study of the features of slang: humor, conciseness, originality and stability. Those features make American slang different from other variety of language. The paper also analyzes the factors influencing American slang, including individual factors and social factors. Individual factors are as follows: gender, occupation, and age. Social factors include drug setting, homosexuality and rock. Then the paper focuses on the social functions of American slang. The first social function is the pursuit of self-identity which is the symbol for dividing the professional groups in society. The second one is to express emotive feeling of the slang users for the psychological need. And the third one is to achieve politeness which means slang serves the phatic function and it contributes to maintain our positive face in daily communication. The paper presents some examples which are from current American slang textbooks, some of them from the original American movies, novels and contemporary American slang dictionaries. The development of slang cannot be separated from the society. As the society highly develops, the use of slang also becomes more complicated as well. It is necessary for students to know more about American slang, in order to achieve a better understanding of American culture and American society.

\section{REFERENCES}

[1] Brook, G. L. (1979). Varieties of English. Oxford: Oxford University Press.

[2] Connie, Eble. (1996). Slang and Sociability. Chapel Hill: University of North Carolina Press.

[3] Chen Linhua. (2006). An Introduction to Linguistics. Jilin: Jilin University Press.

[4] Dai Weidong \& He Zhaoxiong. (2010). A New Concise Course in Linguistics for Students of English (2nd edn.). Shanghai: Shanghai Foreign Language Education Press.

[5] Flexner, Stuart Berg. (1987). New Dictionary of American Slang .Chapman London and Basingstoke: The Macmillan Press.

[6] Hu Zhuanglin. (2006). Linguistics: A Course Book (3rd edn.). Beijing: Beijing University Press.

[7] Hudson, R.A. (1985). Sociolinguistics. London: Cambridge University Press.

Yanchun Zhou was born in Panshi, Jilin Province, China on March 15 th, 1978, who has got a degree of Master of Arts in foreign linguistics and applied linguistics from Changchun University of Science and Technology, Changchun, Jilin Province, China in 2003.

As a an ASSOCIATE PROFESSOR, she teaches Foreign Linguistics for the English major at School of Foreign Languages, Changchun University of Science and Technology. Three published articles are as follows: [1] A Contrastive Study of the Connotative Meaning of Linguistic Signs in English and Chinese (Academy Publisher, Theory and Practice in Language Studies,2011); [2] A Study of Gender differences in English and Chinese (Changchun, Jilin Province: Writer Magazine, 2010); [3] From Wilderness of American Literature to Its Environmental Awareness (Taiyuan, Shanxi Province: Masterpieces Review, 2011). Previous research interests are Linguistics and Semantics. At present she focuses on Pragmatics \& Cognitive Linguistics.

Yanhong Fan was born in Changchun, Jilin Province, China, in 1982, who has got a Master degree in foreign language and literature from Liaoning Normal University, Dalian, Liaoning Province, China in 2008.

As a LECTURER, she teaches British and American Literature for the English major at School of Foreign Languages, Changchun University of Science and Technology. At present she focuses on Comparative Literature. 